Article

\title{
West African Summer Monsoon Precipitation Variability as Represented by Reanalysis Datasets
}

\author{
Kwesi Akumenyi Quagraine 1,2@, Francis Nkrumah ${ }^{2}\left(\mathbb{D}\right.$, Cornelia Klein ${ }^{3,4}$, \\ Nana Ama Browne Klutse ${ }^{5,6, *}$ and Kwesi Twentwewa Quagraine ${ }^{7}$ \\ 1 Climate System Analysis Group (CSAG), Department of Environmental and Geographical Science, \\ University of Cape Town, Private Bag X3, Rondebosch, Cape Town 7701, South Africa; kwesi@csag.uct.ac.za \\ 2 Department of Physics, University of Cape Coast, Private Mail Bag, Cape Coast, Ghana; \\ francis.nkrumah@ucc.edu.gh \\ 3 UK Centre for Ecology \& Hydrology (UKCEH), Wallingford, Oxfordshire OX10BB, UK; cornkle@ceh.ac.uk \\ 4 Department of Atmospheric and Cryospheric Sciences, University of Innsbruck, Innrain 52f, 6020 Innsbruck, \\ Austria \\ 5 Department of Physics, University of Ghana, P.O. Box LG 63, Legon, Accra, Ghana \\ 6 African Institute of Mathematical Sciences (AIMS), Sector Remera, KN 3, Kigali, Rwanda \\ 7 Department of Physics, Kwame Nkrumah University of Science and Technology, Private Mail Bag, Kumasi, \\ Ghana; ktquagraine@st.knust.edu.gh \\ * Corresponding: nklutse@ug.edu.gh
}

Received: 18 August 2020; Accepted: 2 October 2020; Published: 6 October 2020

check for updates

\begin{abstract}
Focusing on West Africa, a region riddled with in situ data scarcity, we evaluate the summer monsoon monthly rainfall characteristics of five global reanalysis datasets: ERA5, ERA-Interim, JRA-55, MERRA2, and NCEP-R2. Their performance in reproducing the West African monsoon (WAM) climatology, interannual variability, and long-term trends for the main monsoon months are compared to gauge-only and satellite products. We further examine their ability to reproduce teleconnections between sea surface temperatures and monsoon rainfall. All reanalyses are able to represent the average rainfall patterns and seasonal cycle; however, regional biases can be marked. ERA5, ERA-Interim, and NCEP-R2 underestimate rainfall over areas of peak rainfall, with ERA5 showing the strongest underestimation, particularly over the Guinea Highlands. The meridional northward extent of the monsoon rainband is well captured by JRA-55 and MERRA2 but is too narrow in ERA-Interim, for which rainfall stays close to the Guinea Coast. Differences in rainband displacement become particularly evident when comparing strong El Niño Southern Oscillation (ENSO) years, where all reanalyses except ERA-Interim reproduce wetter Sahelian conditions for La Niña, while overestimating dry conditions at the coast except for NCEP-R2. Precipitation trends are not coherent across reanalyses and magnitudes are generally overestimated compared to observations, with only JRA-55 and NCEP-R2 displaying the expected positive trend in the Sahel. ERA5 generally outperforms ERA-Interim, highlighting clear improvements over its predecessor. Ultimately, we find the strengths of reanalyses to strongly vary across the region.
\end{abstract}

Keywords: reanalysis; precipitation; West Africa; monsoon; teleconnection; climate monitoring

\section{Introduction}

Understanding precipitation variability over West Africa is important to the population as their economies rely heavily on agriculture to supplement livelihoods, food security, and water availability [1,2]. Generally, rain-bearing systems are embedded in the West African Monsoon (WAM), a large-scale circulation which is characterised by the reversal of wind direction in the lower levels of the atmosphere transporting moisture from the Atlantic ocean inland. Thus, rainfall in the region is 
highly variable on intraseasonal, interannual, and interdecadal timescales [3,4]. Moreover, West Africa has also experienced devastating droughts in the 1970s and 1980s (e.g., [5]), which have been found to be driven by sea surface temperature (SST) influence [6].

Observational datasets needed to understand precipitation variability and its associated changes in atmospheric circulations are notably scarce over the region and even for locations with relatively good coverage, the data may not be easily accessible [6,7]. Thus, a likely alternative approach to tackling this challenge is to resort to reanalysis datasets. In this context, reanalysis datasets represent a global, model-based solution to reconstruct continuous atmospheric fields [8]. Reanalyses are an important source of climate information [9], providing a physically consistent approximation of the state of the atmosphere that allows process-based analyses of rainfall variability and associated atmospheric drivers. It is also useful when we want to evaluate not only rainfall changes but drivers of extreme variability. However, earlier studies (e.g., [10]) have reported inconsistencies in their representation of precipitation, as they, similar to other global atmospheric models, have to rely on parameterisations for the representation of rainfall processes. Furthermore, in most reanalyses, rainfall is a purely diagnostic variable and therefore, does not profit directly from the assimilation of observational data over a data-sparse region like Africa. However, even the boundary conditions crucial for a skilful rainfall representation were found to be comparably ill-constrained [7,11-13].

While there have been numerous studies that evaluate and intercompare multiple reanalysis datasets for other regions [7,14-20], there have been few studies over West Africa despite their importance in climate monitoring and research. A study by [21] focused on Ghana and reported poor performance of reanalyses in reproducing interannual variability, having large biases and unrealistically stronger trends.

Consequently, this paper seeks to evaluate how existing reanalysis datasets represent regional monthly monsoon precipitation information over West Africa and to validate with gridded observations. The added motivation for this study is the availability of the new state-of-the-art ERA5 dataset, which provides an opportunity to gauge improvements in reanalysis techniques and to intercompare with existing ones.

This paper is structured as follows: the data and methods used are described in Section 2. The intercomparison of the reanalyses with respect to observations is discussed in Section 3, followed by a discussion and summary of conclusions in Section 4 .

\section{Data and Methods}

\subsection{Study Area}

West Africa is a region located between latitudes $4-20^{\circ} \mathrm{N}$ and longitudes $17^{\circ} \mathrm{W}-17^{\circ} \mathrm{E}$, and comprises 15 countries (as shown in Figure 1). The region has three main agro-ecological zones, namely the Guinea Coast $\left(4-8^{\circ} \mathrm{N}\right)$, the Savanna $\left(8-12^{\circ} \mathrm{N}\right)$, and the Sahel $\left(12-20^{\circ} \mathrm{N}\right)$ [22]. The climate of the region is mainly driven by the WAM, which accounts for about $70 \%$ of the annual rainfall and is modulated by localised highlands, such as the Guinea highlands $\left(11^{\circ} \mathrm{N}, 10^{\circ} \mathrm{W}\right)$, Jos Plateau $\left(10^{\circ} \mathrm{N}\right.$, $\left.9^{\circ} \mathrm{E}\right)$, and the Cameroon Mountains $\left(5^{\circ} \mathrm{N}, 12^{\circ} \mathrm{E}\right)[23]$. The WAM is a large-scale circulation which is characterised by the reversal in direction of winds in the lower levels of the atmosphere from the Atlantic Ocean transporting moisture into land [24]. This large-scale feature drives the seasonal rainfall pattern in West Africa and exhibits dominant south-westerly winds during the summer monsoon months (June-September, JJAS) and north-easterlies during the dry season months (January-March, JFM). Additionally, the WAM controls the onset, variability, and distribution of rainfall over West Africa and follows the migration of the intertropical discontinuity (ITD) [25]. Given that the region receives maximum rainfall amounts during WAM months, we concentrated on the JJAS period in this study. 


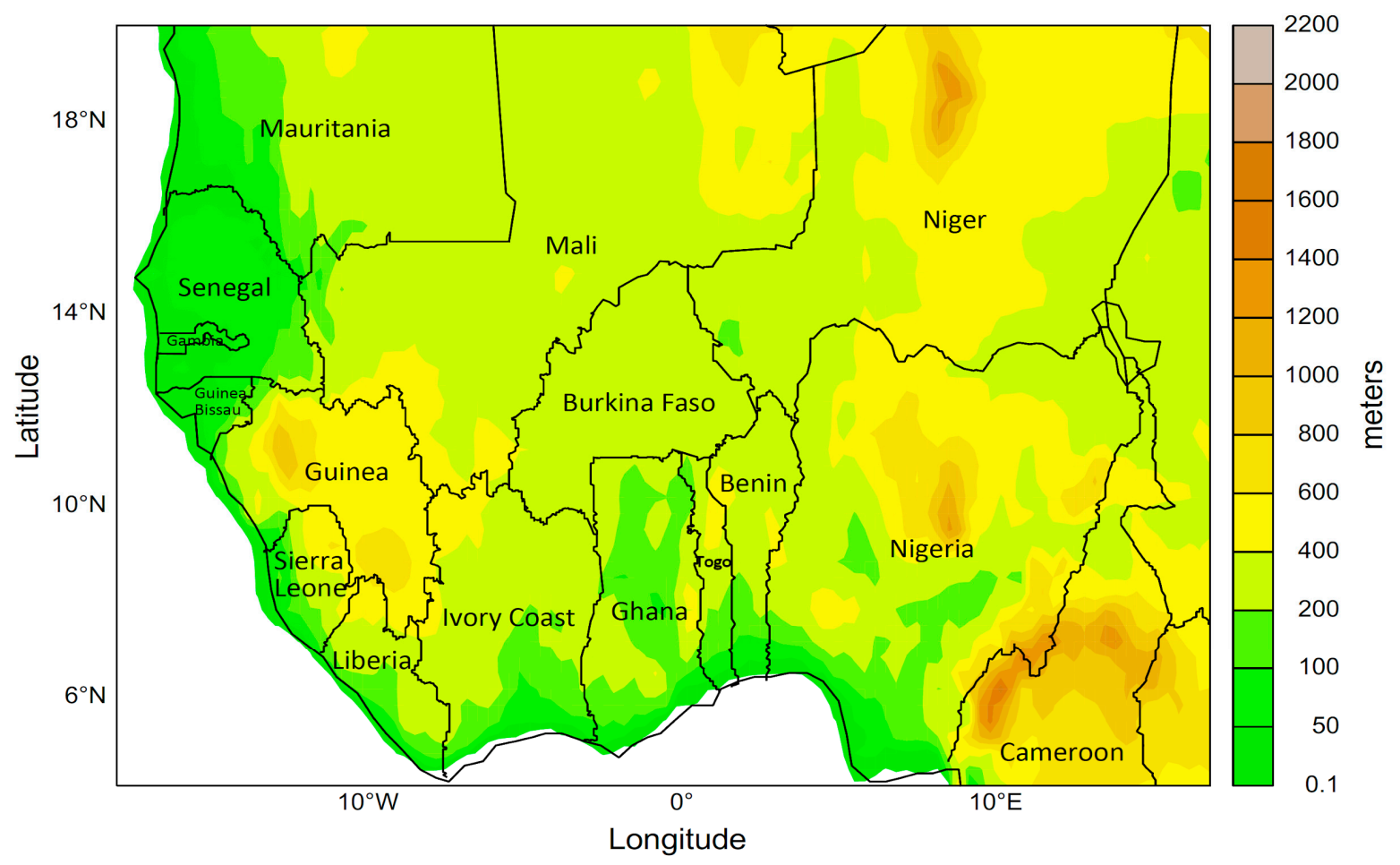

Figure 1. A map of West Africa showing topography and countries. Dark brown areas denote mountainous regions.

\subsection{Data}

This study investigated how five global reanalysis datasets (Table 1) represent regional monthly precipitation information over West Africa relative to observations. The global reanalysis datasets selected are the products commonly used in climate monitoring and research. All datasets were analysed for a 36-year period from 1981 to 2016 and were regridded using an area-weighted average to the reanalysis dataset with the coarsest resolution $\left(2.5^{\circ}\right)$, which was NCEP-R2 for comparison.

\subsubsection{Observation Dataset}

We used two gridded gauge-only and one satellite-based precipitation datasets. The gauge-only datasets were Climatic Research Unit (CRU-TS4.03; [26]), a long-term monthly gridded gauge product at $0.5^{\circ}$ resolution spanning 1901-2018, and the Global Precipitation Climatology Centre (GPCC) Full Data Reanalysis (hereinafter GPCC; $[27,28]$ ). GPCC comes at monthly resolution from 1891 to 2016 and is gridded to $0.5^{\circ}$. While gridded gauge datasets are frequently used as reference datasets in rainfall studies across West Africa (e.g., [11,29]), their accuracy strongly depends on the density of rain gauges. In most regions in West Africa, the gauge coverage tends to be low and is additionally affected by a significant decrease in gauge numbers over the last decades [30,31]. Such spatiotemporal inconsistencies can affect represented spatial rainfall variability, and trends in particular. Complementary to the gauge-only datasets, we therefore used the Climate Hazards Group InfraRed Precipitation with Stations (CHIRPS; [32]). The data input for the satellite dataset combines thermal infrared measurements with other data inputs like passive microwave retrievals and rain gauge measurements, and therefore, profits from rainfall information at high spatiotemporal resolution from various sources. It should be noted that CHIRPS blends rain gauge records from the Global Historical Climatological Network, the Global Summary of the Day, further private contributors, and meteorological agencies with satellite estimates and applies a final gauge-based bias adjustment. Hence, CHIRPS cannot be interpreted as an independent data source but is useful for evaluating spatial consistency with the gauge-only products. 
For presented analyses, we used CRU-TS4.03 (hereafter CRU) as a reference dataset for comparison with the other observations and the reanalysis datasets for the study period.

\subsubsection{Global Reanalysis Datasets}

(a) ERA5

ERA5 is the latest high-resolution reanalysis produced by the European Centre for Medium-Range Weather Forecast (ECMWF) Integrated Forecast System (IFS Cycle 41r2) to replace their ERA-Interim product. The new reanalysis incorporates variables such as sea surface temperature (SST), sea ice, and aerosols as inputs, making it suitable for climate simulation. The data have a spatial resolution of $31 \mathrm{~km}$ with 137 levels. ERA5 uses a 12-hourly 4D-Var data assimilation ensemble and additionally uses a 10-member ensemble of data assimilations at $63 \mathrm{~km}$ resolution for its uncertainty estimates [33]. ERA5 is available from 1979 to present, although there are plans to eventually extend the period well into 1950.

(b) ERA-Interim

ERA-Interim is the version of reanalysis to be retired in August 2019. The dataset is produced with the ECMWF Integrated Forecast System (IFS Cycle 31r2), which is a forecast model fully coupled with components for the atmosphere, land surface, and ocean waves. ERA-Interim also has a 12-hourly $4 \mathrm{D}$-Var data assimilation ensemble with a spatial resolution of about $79 \mathrm{~km}$ on 60 levels [34].

(c) JRA-55

JRA-55 is the second version of reanalysis from the Japanese Meteorological Agency (JMA). It is based on a $4 \mathrm{D}$-Var data assimilation with 60 atmospheric levels. It is currently the longest of the reanalyses and has a horizontal resolution of $55 \mathrm{~km}$ [35]. The sea-ice albedo of the model used is a function of solar zenith angle and skin temperature [36].

Table 1. Details of the five global reanalyses used in the present study.

\begin{tabular}{cccccc}
\hline & ERA5 & ERA-Interim & JRA-55 & MERRA-2 & NCEP-R2 \\
\hline Model Resolution & TL639 L137 & TL255 L60 & TL319 L60 & $\begin{array}{c}\text { 72 sigma } \\
\text { levels }\end{array}$ & T62 \\
Grid spacing & $0.25^{\circ} \times 0.25^{\circ}$ & $0.75^{\circ} \times 0.75^{\circ}$ & $1.25^{\circ} \times 1.25^{\circ}$ & $0.625^{\circ} \times 0.5^{\circ}$ & $2.5^{\circ} \times 2.5^{\circ}$ \\
$\quad$ lon $\times$ lat $)$ & $4 \mathrm{D}-$ Var & $4 \mathrm{D}-$ Var & $4 \mathrm{D}-$ Var & 3D-Var & 3D-Var \\
Assimilation method & 1981-2016 & 1981-2016 & $1981-2016$ & $1981-2016$ & $1981-2016$ \\
Period Used & {$[33]$} & {$[34]$} & {$[35]$} & {$[37,38]$} & {$[39]$} \\
Reference & & & & & \\
\hline
\end{tabular}

\section{(d) MERRA-2}

MERRA-2 is a reanalysis from The National Aeronautics and Space Administration (NASA) current version of the Goddard Earth Observing System Model, version 5 (GEOS-5), Data Assimilation System, covering the modern satellite era. It uses a 3D-Var data assimilation on 72 sigma levels at a resolution of $0.625^{\circ}$. The MERRA-2 is an updated version of MERRA and consists primarily of improvements on the dynamics and physics and incorporates more satellite observations $[37,38]$.

\section{(e) NCEP-R2}

The National Centers for Environmental Prediction reanalysis version 2 (NCEP-R2) is available from 1979 to the present day and has a resolution of $2.5^{\circ}$ with 28 vertical sigma levels. It uses a 3D-Var data assimilation technique with a fully coupled atmosphere-ocean-land model [39]. The data are an improvement on its earlier version NCEP-R1. 


\subsection{Methods}

For the assessment of rainfall variability in the reanalysis datasets with reference to observations, different methods were used. Firstly, the mean bias between the five reanalysis datasets and CRU, the standard deviation, and linear trend over West Africa were calculated for the summer monsoon season JJAS between 1981 and 2016. The non-parametric Mann-Kendall trend test [40,41] was employed to explicitly locate significant linear trends in precipitation over the region. The Pearson correlation coefficient was furthermore applied to evaluate interannual co-variability between CRU and the other datasets. Rainfall variability in JJAS was correlated with SSTs in order to examine the relative importance of SST anomalies for precipitation distribution over West Africa. All the tests were implemented at the 5\% significance level. We used the following open-source packages in Python for the data processing and analysis presented in this study: NumPy [42], pandas [43], xarray [44], Matplotlib [45], and Salem [46].

In order to ascertain the magnitude of variance in rainfall anomalies for the considered datasets, an empirical orthogonal function (EOF) analysis was conducted to identify coherent patterns in the summer rainfall season. In addition, we assessed the capacity of the reanalysis datasets to reproduce the sensitivity of West African rainfall to the ENSO, based on composites of consensus dry (wet) years as defined in [47] and shown in Table 2. Here, a consensus year was characterised by widespread dry (wet) conditions that simultaneously overlap with an El Niño (La Niña) event for all reference datasets over the period of this study (1981-2016). Since the West African area exhibits a rainy season with an annual maximum precipitation occurring in August, the spatial structure of precipitation for this month is analysed to investigate the effect of ENSO on the maximum seasonal rainband displacement. The observation and reanalysis datasets were used to obtain a broader perspective of the rainfall climatology and variability over West Africa during the summer monsoon (JJAS) season.

Table 2. The consensus years of strong and very strong El Niño (La Niña) as outlined in [47].

\begin{tabular}{cc}
\hline Consecutive Dry Years & Consecutive Wet Years \\
\hline $1988,1998,1999,2010$ & $1983,1987,1997,2002$ \\
\hline
\end{tabular}

\section{Results}

\subsection{Rainfall Average and Seasonal Cycle}

We examined precipitation characteristics in the monsoon rainfall season (JJAS) for West Africa (Figure 2). The rainfall climatology from CRU (Figure 2a) displays two core regions with the highest rainfall amounts, one over Liberia and Sierra Leone with a strong maximum of $14 \mathrm{~mm} \mathrm{day}^{-1}$ and the other maximum over the southern part of the border between Nigeria and Cameroon. Owing to the wet climate, these two peak regions tend to be areas with dense vegetation cover. CRU displays a zonal gradient with rainfall decreasing from the east and west sides towards the central part of the region. The GPCC and CHIRPS datasets overall show a similar rainfall distribution, with only small biases compared to CRU (Figure $2 b, c$ ), likely due to shared reference rain gauge data amongst the compared products. Thus, all observation datasets show good agreement and from here on, we discuss the reanalysis datasets in comparison to CRU.

All reanalyses, with the exception of JRA-55 (Figure 2f), exhibit a dipole pattern with rainfall overestimation to the south and a widespread underestimation to the northern parts of West Africa, which suggests an insufficient northward migration of the monsoon rainband. It can be noted that ERA5, ERA-Interim, and NCEP-R2 (Figure 2d,e,h) reproduce the rainfall behaviour with an underestimation over the two peak areas, with ERA5 showing the strongest underestimation to the reference dataset. Although ERA5 and ERA-Interim (Figure 2d,e) exhibit comparably similar bias patterns, ERA5 shows a high bias with a standard deviation of $\pm 2.2 \mathrm{~mm} \mathrm{day}^{-1}$ over large parts of the region as compared to a standard deviation of $\pm 1.3 \mathrm{~mm} \mathrm{day}^{-1}$ for ERA-Interim. 
(a) CRU TS4.03

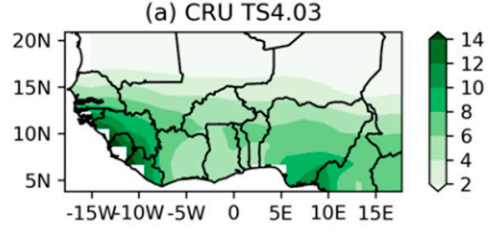

(d) ERA5 [2.2]

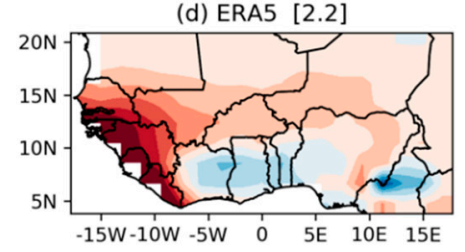

(b) GPCC $[0.6]$

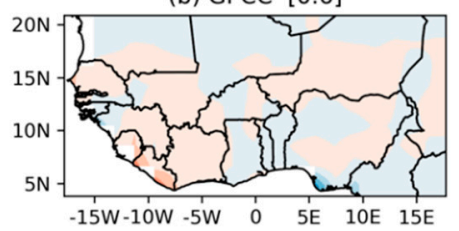

(e) ERA-interim [1.3]

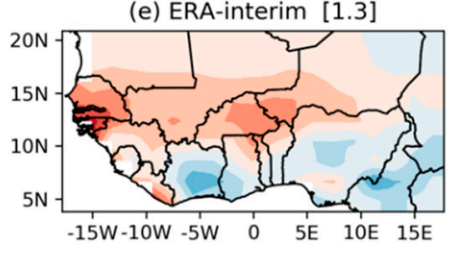

(g) MERRA2 [3.3]

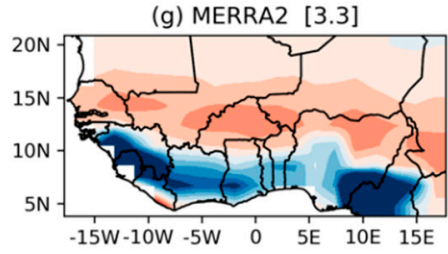

(c) CHIRPS [0.7]

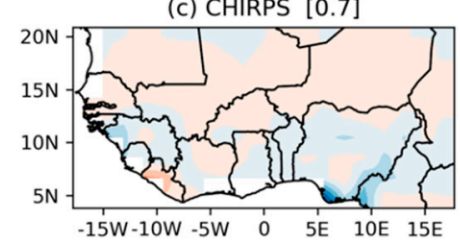

(f) JRA-55 [1.6]

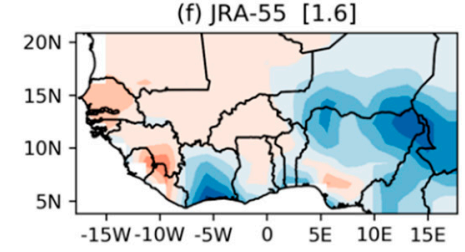

(h) NCEP-R2 [1.7]

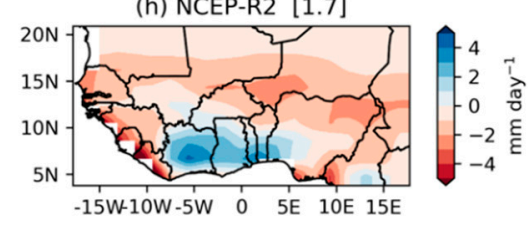

Figure 2. Spatial distribution of mean JJAS precipitation $\left(\mathrm{mm} \mathrm{day}^{-1}\right)$ over West Africa for three observations (a-c); CRU, GPCC, and CHIRPS, and five reanalysis datasets $(\mathbf{d}-\mathbf{h})$. Plot shows mean differences from CRU for the 1981-2016 period. Standard deviations of the mean rainfall bias are shown in box brackets. JJAS-June-September; CRU—Climate Research Unit; GPCC—Global Precipitation Climatology Centre; CHIRPS—Climate Hazards Group InfraRed Precipitation with Stations.

MERRA2, on the other hand, depicts an overestimation over these two maximum areas with a higher standard deviation of $\pm 3.3 \mathrm{~mm}^{-1} \mathrm{yy}^{-1}$. It can be inferred that MERRA2 is too wet across the southern/coastal belt of the region, which again suggests a southward-displaced monsoon band with too high rainfall intensities (Figure $2 \mathrm{~g}$ ).

Likewise, there is a high bias in JRA-55 over Cameroon, Nigeria, southern Niger, and Ivory Coast (Figure 2f). The NCEP-R2 (Figure 2h) shows a widespread negative bias over the entire region with high biases over Sierra Leone and Liberia.

In a next step, we explore the interannual variability of the seasonal cycle averaged across our West Africa domain. On the domain average, the monsoon precipitation depicts a unimodal distribution pattern, which all reanalyses are able to reproduce (Figure $3 \mathrm{~d}-\mathrm{h}$ ), as identified by CRU, GPCC, and CHIRPS (Figure 3a-c). Likewise, the reanalysis accurately locates the peak precipitation month (typically August) as in the observation datasets. However, there are some differences in the estimation of the magnitude of the total precipitation. For instance, ERA5, ERA-Interim, and NCEP-R2 (Figure 3d,e,h) all show lower precipitation values during the peak precipitation month compared to both gauge-only and satellite-based observations, as well as for the other reanalyses, where values were $\geq 5.0 \mathrm{~mm} \mathrm{day}^{-1}$.

There are also notable differences in how most reanalyses capture precipitation in the dry season months November-February. While precipitation in these months are minimal in the observations, most reanalyses exhibit rainfall between 0.5 and $1.0 \mathrm{~mm} \mathrm{day}^{-1}$ on the domain average (e.g., ERA-Interim, JRA-55, MERRA2; Figure 3e-g). This overestimation of dry season rain seems to have considerably improved in ERA5 (Figure 3d).

Finally, outside of the main monsoon months JJAS, interannual precipitation variability tends to be higher in the reanalyses than the observations, as indicated by a larger monthly spread. For the relative interannual variability for the summer months among reanalyses, JRA-55 shows less variation of $\pm 13 \%$ from its long-term average rainfall bias, with NCEP-R2 recording the highest variation of $\pm 22 \%$. JRA-55 can be said to be more dependable, in terms of average rainfall bias estimates during the summer in a given year than the other reanalysis datasets. 

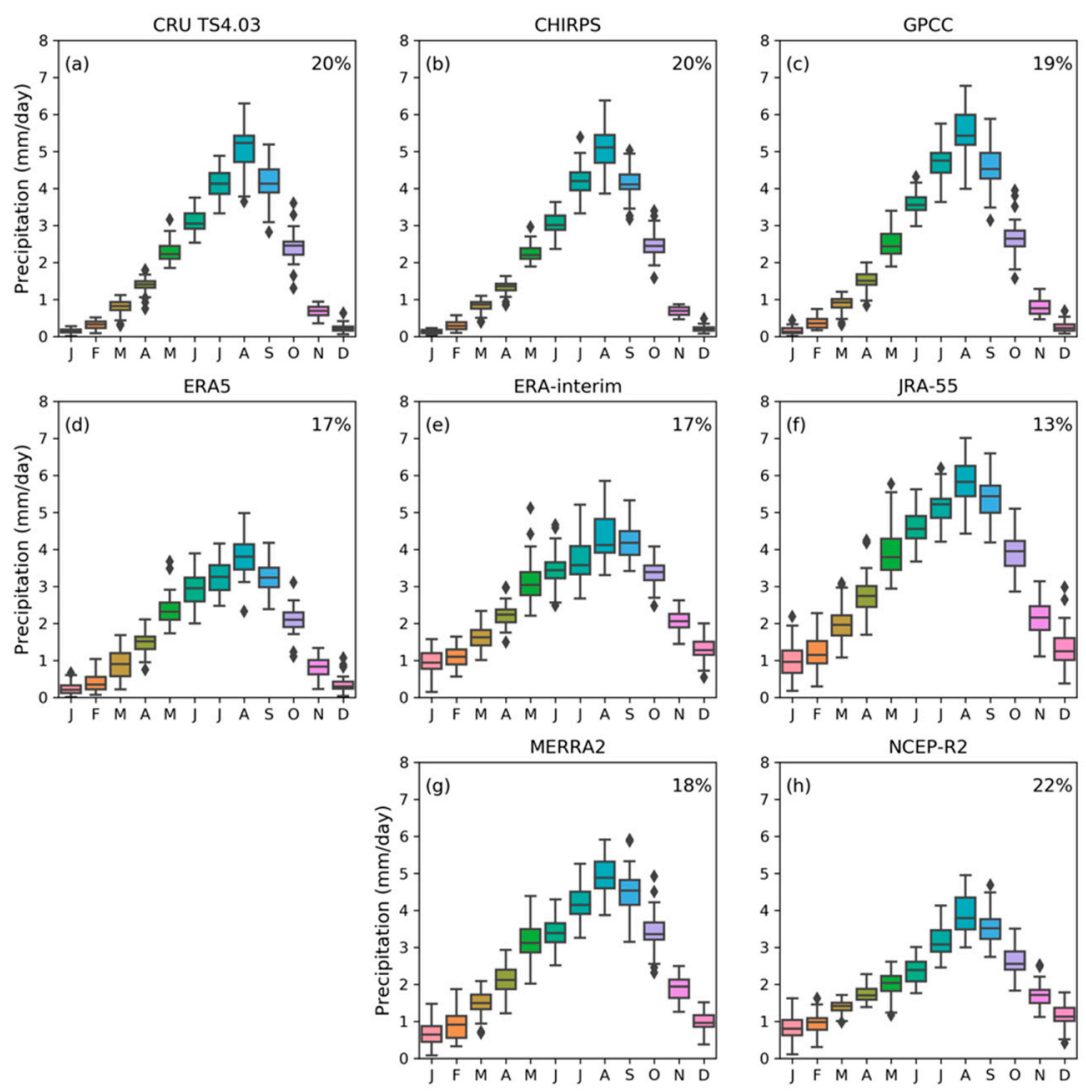

Figure 3. Seasonal cycle with interannual variability of monthly mean precipitation for each dataset over West Africa from 1981 to 2016. Letters on the x-axis represent calendar month. Percentage at the top right depicts the mean relative standard deviation for JJAS. Boxes depict the median within the interquartile range, the whiskers depict the lines that extend to the highest and lowest observations, and the diamonds (outliers) represent values so far removed from other values in the distribution. (a) CRU, (b) GPCC, (c) CHIRPS, (d) ERA5, (e) ERA-Interim, (f) JRA-55, (g) MERRA2, (h) NCEP-R2.

An intercomparison of the 36-year standard deviation of observations and reanalyses for the mean summer precipitation highlights significant differences in the position and magnitude of the maximum spatial variability (Figure 4). In CRU, the region of maximum variability is located along the Liberia-Senegal coast (Figure 4a). This is particularly not surprising as precipitation along the Liberia-Senegal coast is much higher than average precipitation for most parts of the region. Precipitation variability over this area is much lower in ERA5, ERA-Interim, and JRA-55 (Figure 4d-f) in comparison to MERRA2 and NCEP-R2 which show much higher variability along this region (Figure $4 \mathrm{~g}, \mathrm{~h}$ ). In addition to high variability over the Liberia-Senegal coast, MERRA2 and NCEP-R2 also exhibit a pronounced variability along the Guinea Coast. 
(a) CRU TS4.03

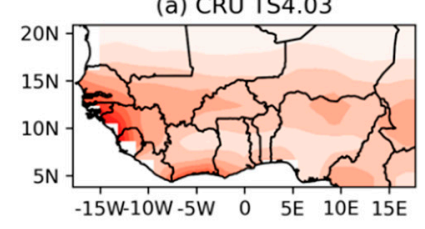

(d) ERA5

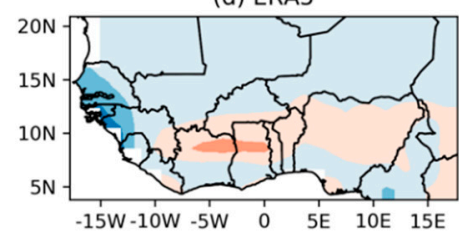

(b) GPCC
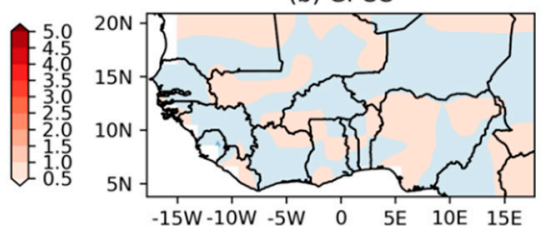

(e) ERA-interim

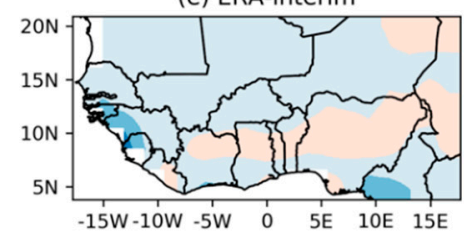

(g) MERRA2

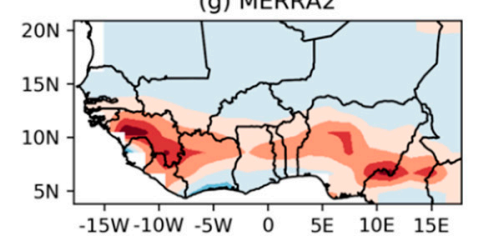

(c) CHIRPS

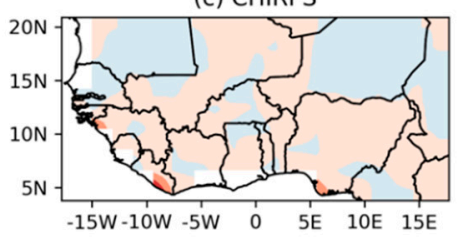

(f) JRA-55

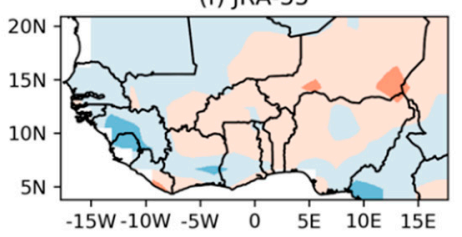

(h) NCEP-R2

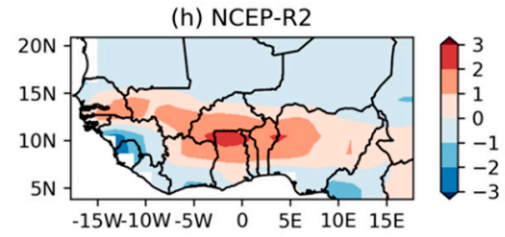

Figure 4. Interannual standard deviation of mean JJAS precipitation $\left(\mathrm{mm} \mathrm{day}^{-1}\right)$ over West Africa for three observations $(\mathbf{a}-\mathbf{c})$; CRU, GPCC, and CHIRPS, and five reanalysis datasets $(\mathbf{d}-\mathbf{h})$. Plot shows mean differences from CRU for the 1981-2016 period.

Figure $5 \mathrm{a}, \mathrm{b}$ clearly shows that the observation datasets agree in the spatial patterns of interannual variability with significant positive correlation $(\geq 0.80)$ over most parts of the region. Among the reanalysis datasets (Figure $5 \mathrm{c}-\mathrm{g}$ ), ERA5 and MERRA2 reasonably reproduce the spatial variations, depicting a significant positive spatial correlation $(\geq 0.30)$ over most parts of West Africa. In comparison, JRA-55 and NCEP-R2 show significant positive correlations $(\geq 0.40)$ across the Sahel, while ERA-Interim displays significant positive correlations $(\geq 0.30)$ over the northwest and coastal parts of the region.

(a) GPCC
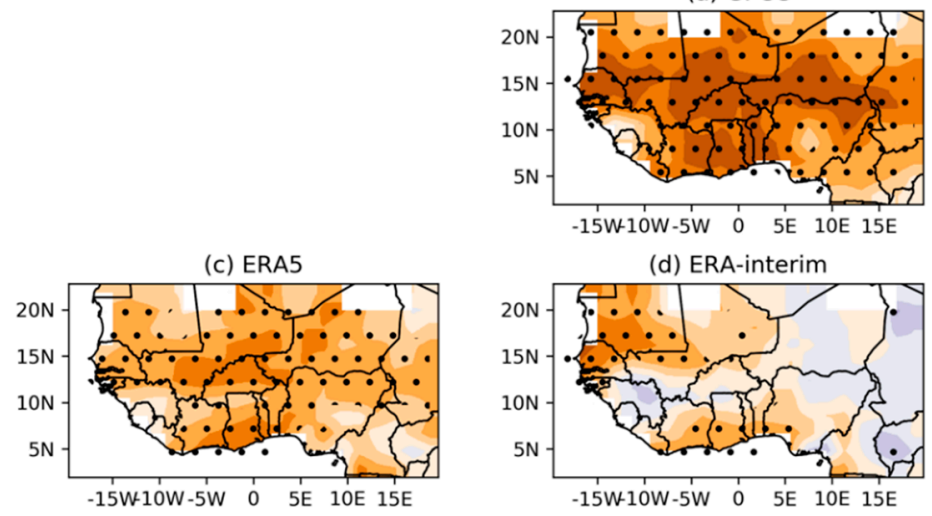

(d) ERA-interim

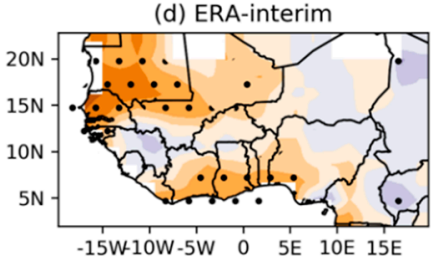

(f) MERRA2

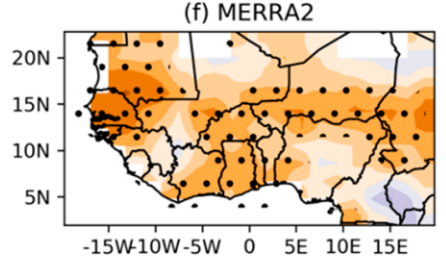

(b) CHIRPS

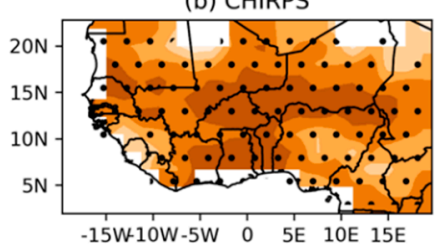

(e) JRA-55

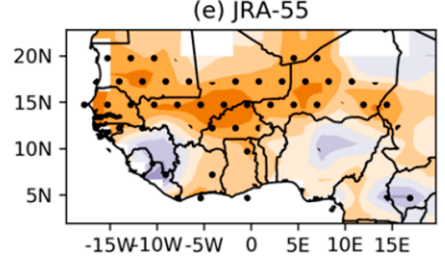

(g) NCEP-R2

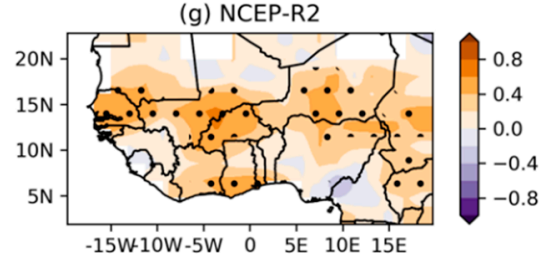

Figure 5. Correlation coefficient (r) maps of pixel-wise temporal correlation of the annual mean JJAS precipitation $\left(\mathrm{mm} \mathrm{day}^{-1}\right)$ between CRU and other observational and reanalysis datasets. Stippling denotes statistically significant correlations at the $5 \%$ significance level. 
As noted in earlier studies, precipitation variability over West Africa can primarily be grouped into two (dipoles) large scale patterns. This variability is modulated in one part by oceanic (between 0 and $10^{\circ} \mathrm{N}$ ) and in another part by continental (between 10 and $20^{\circ} \mathrm{N}$ ) convergence, which occurs as a result of the position of the monsoon rainband and land-atmosphere interactions [48-51]. The ability of the reanalyses to represent the northward extent of the monsoon band is examined as this is an important feature of the West African climate and crucial for rain distribution across the region.

Figure 6 shows total variance explained by the leading Empirical Orthogonal Function (hereafter EOF1) mode. For CRU, about $55 \%$ of the total variance is explained by EOF1, which is characterized by a dipole with a change in sign around $8^{\circ} \mathrm{N}$ (Figure 6a). The total variance explained by EOF1 for GPCC and CHIRPS is $45 \%$ and 55\%, respectively (Figure $6 \mathrm{~b}, \mathrm{c}$ ). The leading EOFs of all reanalyses (Figure $6 \mathrm{~d}-\mathrm{h}$ ) show similar dipole patterns, although there are differences with its location and strength, which implies the reanalyses representing varying meridional shifts of the monsoon band. In ERA5 (Figure 6d), EOF1 constitutes about $53 \%$ of the total variance, while it is $38 \%$ for ERA-Interim (Figure 6e). Similarly, EOF1 constitutes $37 \%, 39 \%$, and $68 \%$ of total variance in JRA-55, MERRA2, and NCEP-R2, respectively (Figure $6 \mathrm{f}-\mathrm{h}$ ). There is a much stronger dipole pattern in all reanalyses except ERA5. For NCEP-R2 (Figure 6h), the pattern along the Guinea coast is shifted to the west. The dipole pattern in ERA5 is much similar to the observations, although it does not capture the strength along the Liberia-Senegal coast. It is worth mentioning ERA-Interim has a stronger dipole strength when compared with the ERA5, although the dipole location is similar. Other studies $[24,29]$ have shown that the precipitation band in the ERA-Interim stays further south during peak monsoon season, resulting in a narrower rainfall band (e.g., Figure 6e) with increased rainfall during the little dry season (occurs when the monsoon band migrates north) along the coast and less rain in the Sahelian parts of the domain. It is observed generally that the explained variances of the EOF modes among reanalysis are lower than that of CRU and CHIRPS, except for NCEP-R2 which shows an overestimation. There is therefore an underestimation in rainfall variability over West Africa in ERA-Interim, JRA55, MERRA2, and ERA5, although variability in ERA5 is very close to the reference dataset.

(a) CRU TS4.03, EOF1, 55\%

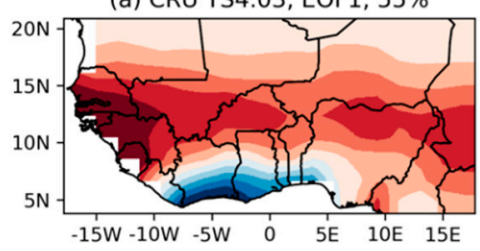

(d) ERA5, EOF1, 53\%

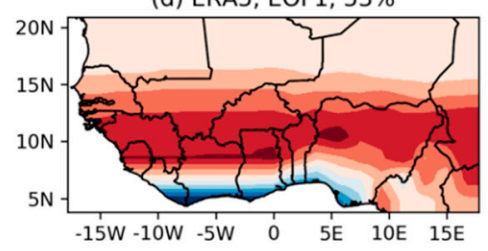

(b) GPCC, EOF1, 45\%

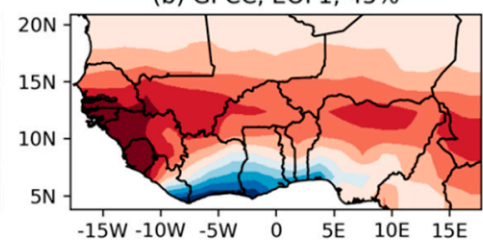

(e) ERA-interim, EOF1, 38\%

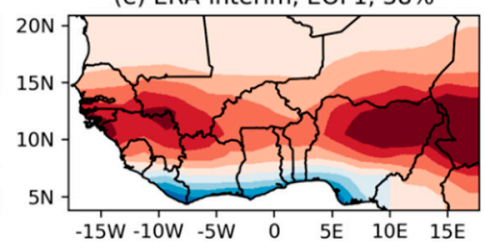

(g) MERRA2, EOF1, 39\%

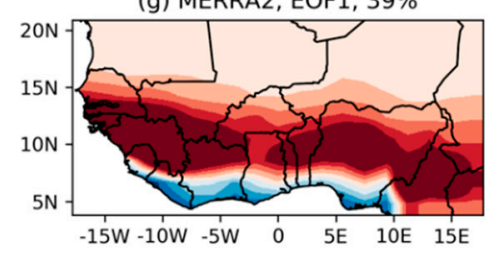

(c) CHIRPS, EOF1, 55\%

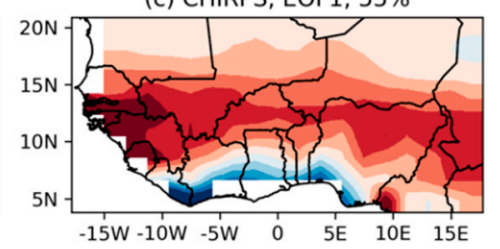

(f) JRA-55, EOF1, 37\%

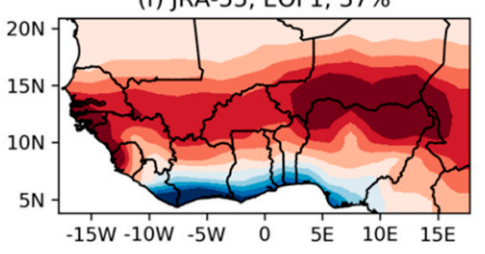

(h) NCEP-R2, EOF1, 68\%

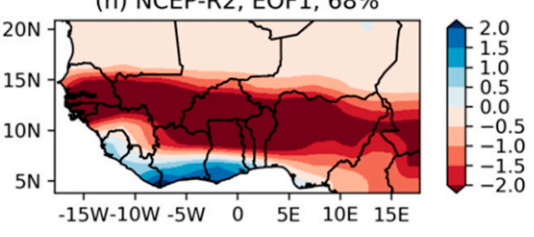

Figure 6. Leading empirical orthogonal function (EOF1) patterns of the mean JJAS precipitation from the 1981-2016 period for CRU, GPCC, CHIRPS, and the reanalysis datasets. The variance explained by each EOF for each dataset is shown at the top-right-hand side of each panel member. 


\subsection{Precipitation Trends and Bias Drift}

As a next step, we consider the linear trend of mean summer precipitation for the reference period for all reanalyses in comparison to observations. In the observations (Figure 7a-c), a mostly insignificant decreasing trend is observed over the coastal regions, while a significant wetting tendency is found in most parts of the region lying above $10^{\circ} \mathrm{N}$ in the Sahel. ERA5 (Figure 7d) produces a weak dipole signal but without any significant trends except in the east of West Africa, over Cameroon. A widespread significant drying is exhibited in ERA-interim (Figure 7e) across the West African region with only a few patches of increased precipitation over southern Nigeria and the coast of Sierra Leone and Liberia. JRA-55 (Figure 7f) reproduces the decline in rainfall over the south but with an overestimation extending further east and west over the region and also an overestimated wetness over the Sahel and central Guinea coast (Togo, Benin, and southern Nigeria). MERRA2 reanalysis (Figure 7g) exhibits an inverse trend with significant wetting tendency over the south and a significant dryness to the southeast part and north of Ivory Coast. NCEP-R2 (Figure 7h) captures a significant wetting regime over the Sahel and Nigeria, with a patch of rainfall decline to the southwestern part of West Africa. The large differences in precipitation trend patterns and magnitudes across the datasets illustrate the limitations in inferring rainfall changes and associated atmospheric drivers from reanalyses alone. Precipitation trends will be sensitive to changes in atmospheric moisture, which are particularly uncertain in the reanalyses (e.g., [12,52]). A study by [31] illustrated that there can be large discrepancies even amongst observational datasets, particularly between different satellite products. However, although trend magnitudes vary, the positive rainfall trend in the Sahel seems to be a robust feature across observations, which ERA-Interim and ERA5 do not reproduce.
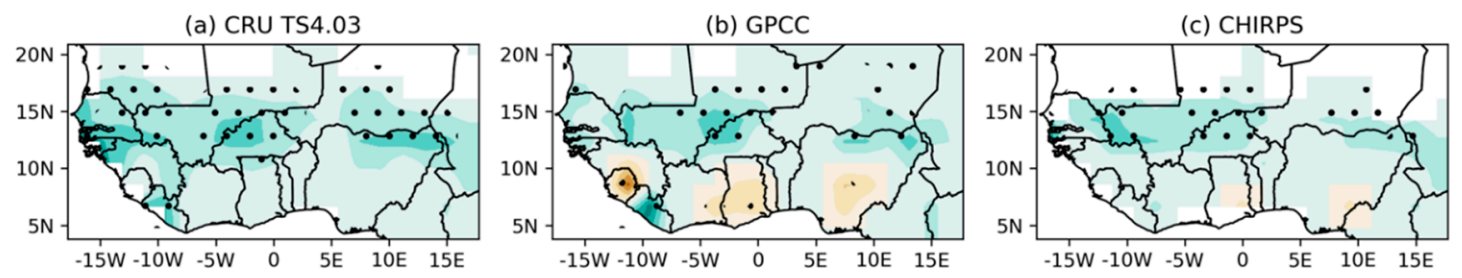

(d) ERA5
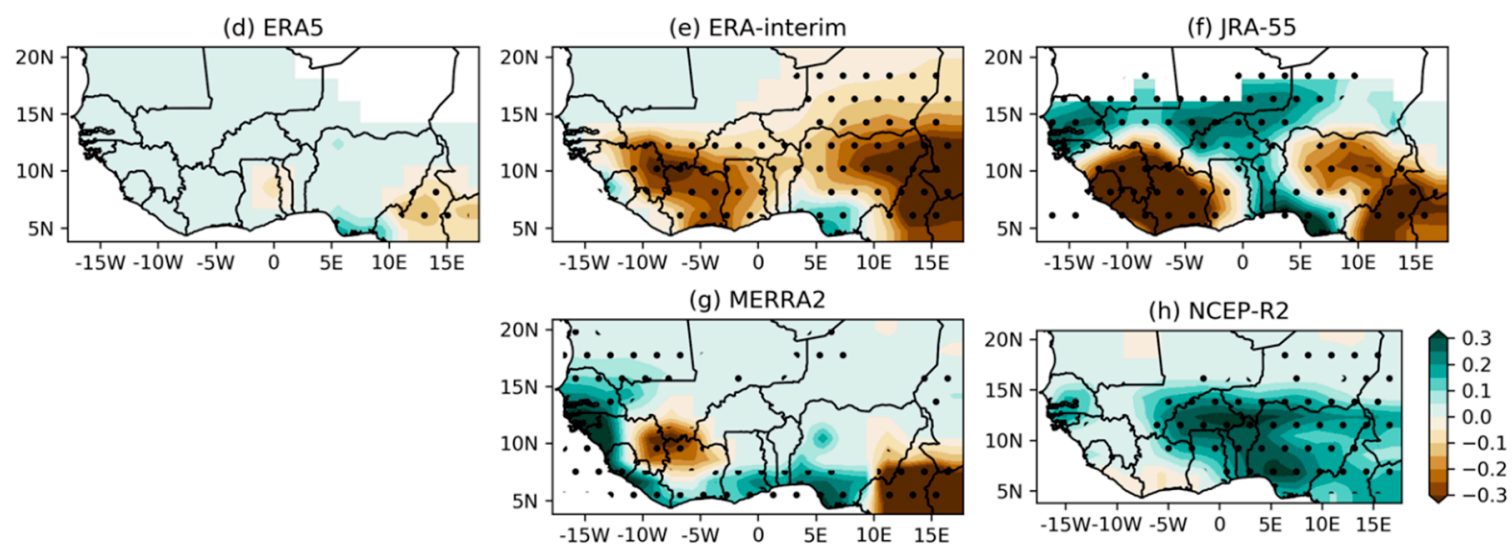

Figure 7. Spatial patterns of the JJAS precipitation linear trend for 1981-2016 (mm per day per decade) from observations $(\mathbf{a}-\mathbf{c})$ and five reanalyses $(\mathbf{d}-\mathbf{h})$. Stippling denotes statistically significant trends at the $5 \%$ significance level.

Since illustrated discrepancies in trends may be linked to temporal inhomogeneities in the datasets, Figure 8 shows the differences between the mean rainfall time series of CRU gauge-based and the other datasets, evaluating the temporal stability of biases. While the gauge-based dataset GPCC, the satellite dataset CHIRPS, and the reanalysis dataset MERRA2 display relatively small deviations from the CRU gauge analysis with a bias $\leq 0.5 \mathrm{~mm} \mathrm{day}^{-1}$, all other datasets show a larger difference and significant variations from the normal. The relatively good agreement of CRU with the GPCC, CHIRPS, and MERRA2 datasets (bias of $\pm 0.5 \mathrm{~mm} \mathrm{day}^{-1}$ ) increases the confidence in the represented 
average temporal variability over the West African region of those datasets. On the contrary, the total rainfall in ERA-Interim decreased notably over time, resulting in a negative bias after 1995 which is in line with the widespread negative trend in Figure 7e. This inhomogeneity seems to have improved in its successor ERA5. Such temporal changes observed among datasets can be related to changes in observational systems and new assimilated data sources [20] as well as and also methodological differences in the estimation algorithm and interpolation techniques, which can affect the variability in rainfall records [31].

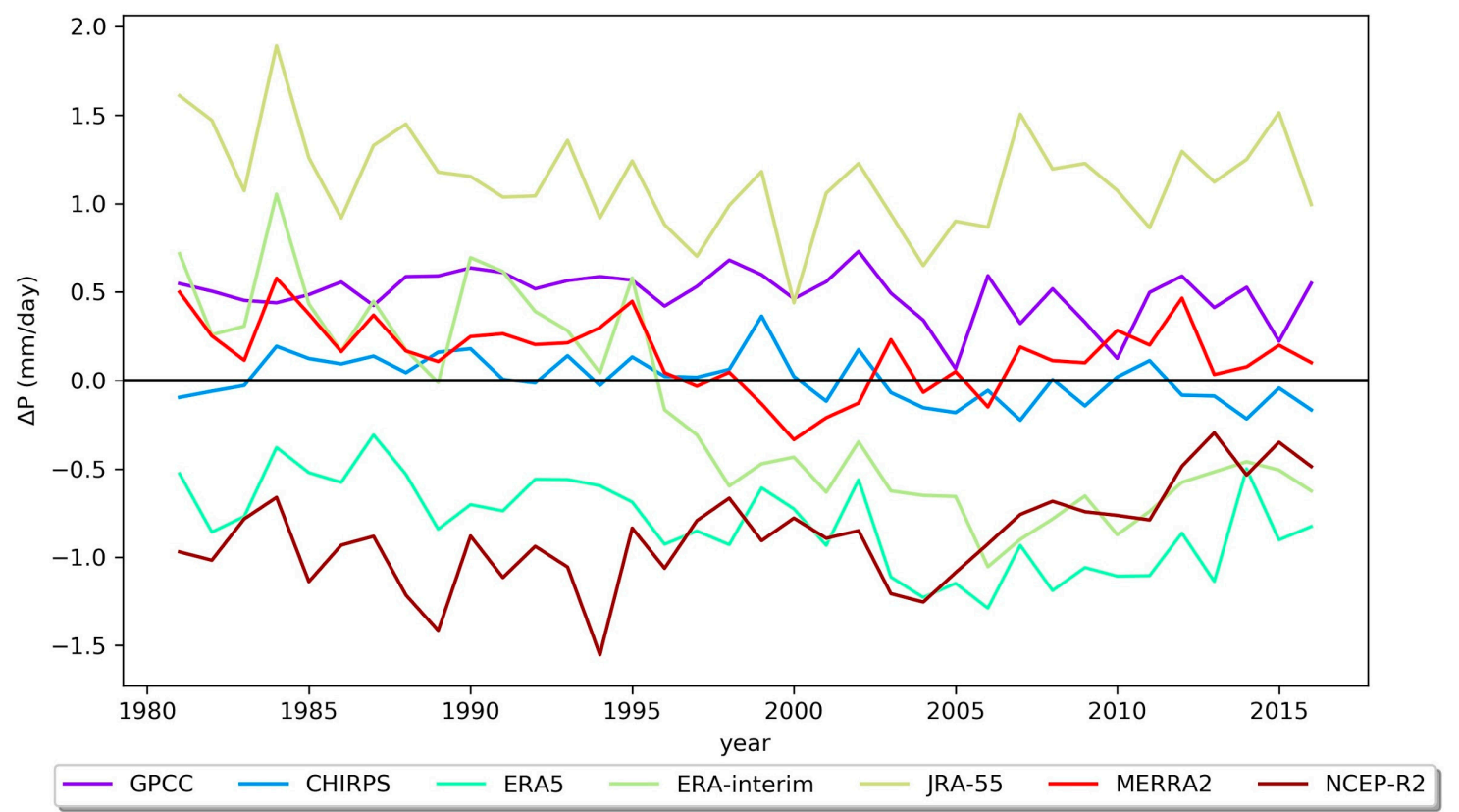

Figure 8. Time evolution of regional mean JJAS rainfall difference between CRU and other observational and reanalysis datasets averaged over West Africa.

\subsection{Teleconnections of West African Rainfall}

The particular usefulness of reanalysis datasets comes from their internal consistency between variables, helping us understand the relationships between regional rainfall variability and large-scale drivers. There is a well-documented non-stationary interannual relationship between anomalies of tropical SSTs and WAM precipitation [48-50,53-55]. The first mode of variability of the Tropical Atlantic (Atlantic Niño, [56]) is characterised by anomalously high SST in the eastern equatorial Atlantic basin and the displacement of the WAM convective region southward and eastward, most pronounced in summer, and leading to wetter conditions at the Guinea Coast $[57,58]$. At the same time, the authors in [59] assert that the association between SSTs along the Guinea coast and rainfall is positive. It had been suggested earlier by [55] that this relationship may on the other hand induce droughts in the Sahel, creating a rainfall dipole. While until the 1970s, these tropical south Atlantic (TSA) SST (hereafter TSA-SST) variability modes were most dominant in influencing the WAM, tropical Pacific SSTs have gained importance since, with significantly related negative (positive) WAM anomalies to El Niño (La Niña) events [57].

As a means to characterise this important feature of the region, we consider the correlation between the TSA-SST index (hereafter TSA index) [60] and mean summer precipitation over West Africa for observations and reanalyses (Figure 9). The TSA index is typically defined over a grid box of $30^{\circ} \mathrm{W}-10^{\circ} \mathrm{E}, 0^{\circ}-20^{\circ} \mathrm{S}$ and is based on the Reynolds OIv2 SST analysis [61]. 
(a) CRU TS4.03

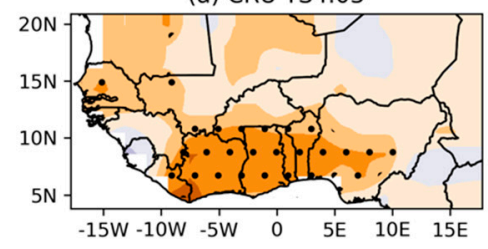

(d) ERA5

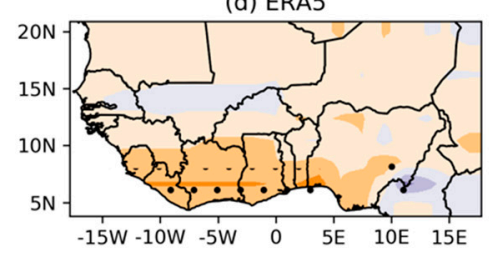

(b) GPCC

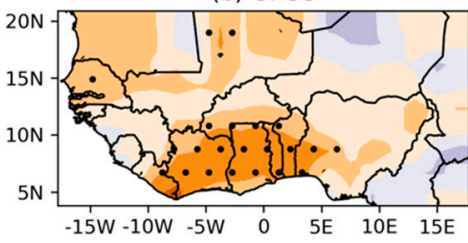

(e) ERA-interim

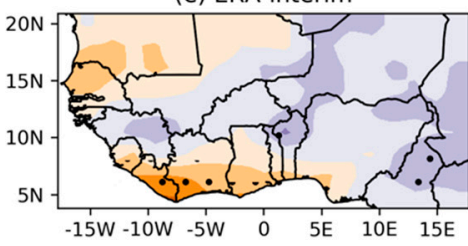

(g) MERRA2

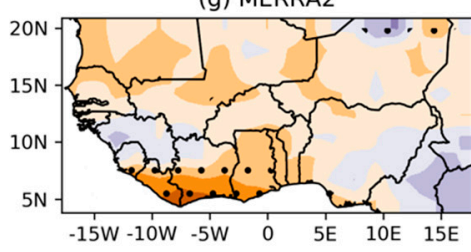

(c) CHIRPS

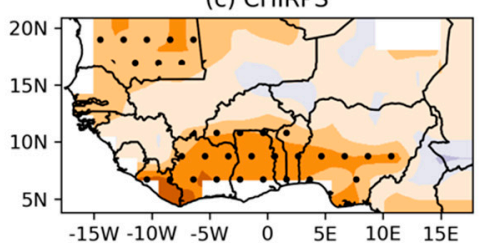

(f) JRA-55

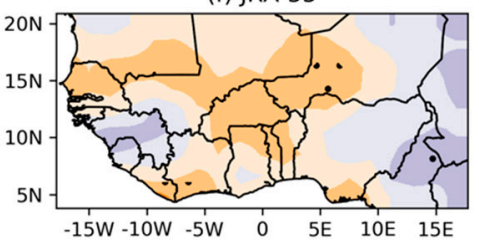

(h) NCEP-R2

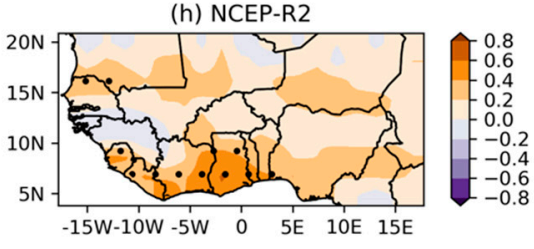

Figure 9. Correlation between Tropical South Atlantic (TSA) SST and mean JJAS precipitation for CRU, GPCC, CHIRPS, and the reanalysis datasets over West Africa. Stippling denotes statistically significant trends at the $5 \%$ significance level.

Both gauge-based and satellite-based observational datasets display similar distribution in the correlation of SSTs to rainfall intensities over West Africa (Figure 9a-c): weak non-significant correlations depict reduced rainfall in the Sahel during warmer TSA periods but coastal rainfall increases dominate, as discussed above. Most reanalyses (e.g., Figure $9 d-h$ ) reproduce this pattern albeit with stronger/weaker correlations over certain parts of the domain. Different from all other datasets, JRA-55 exhibits a split in the correlation band along the coast, which spreads northwards to the Sahel and as a result, leaves the entire eastern part of the region negatively correlated, although weak. ERA-Interim (Figure 9e) also shows a stronger negative correlation around the Sahel, with a band spreading from the Cameroon Mountains towards the Guinea Highlands. ERA5 (Figure 9d) shows an improvement over ERA-Interim (Figure 9e) in its representation; however, positive correlations along the coast are weaker compared to observations. ERA5, MERRA2, and NCEP-R2 reanalyses tend to give a good representation of the correlation features in the reference dataset, albeit with the region of positive rainfall correlation not reaching far enough inland.

Figure 10 displays the difference between wet and dry consensus years. By definition, wet consensus years are associated with more rainfall north of $10^{\circ} \mathrm{N}$ in the observations, which coincides with a slight decrease in rainfall along the coast compared to the dry consensus condition. This suggests that during dry consensus years the centre of the rainband stayed further south below $10^{\circ} \mathrm{N}$. The northernmost position in the rainband shift between La Niña and El Niño years is approximately captured by JRA-55, NCEP-R2, and to a lesser degree, MERRA2 (Figure 10f-h), while ERA5 clearly underestimates the northward extent in the west and depicts a strongly zonal behaviour. Yet, it shows clear improvement over ERA-Interim, which does not seem to produce a coherent rainband displacement (Figure 10e). On the other hand, drier coastal conditions are not visible in NCEP-R2 (Figure 10h). The amplitude of maximum rainfall intensity in the reanalysis datasets spreads more to the east, especially in MERRA2. These consensus wet years therefore tend to record more rains over the Sahel, leading to some of the massive flooding observed over the Sahel region [5]. 
(a) CRU TS4.03

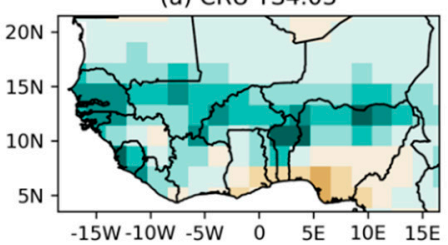

(d) ERA5

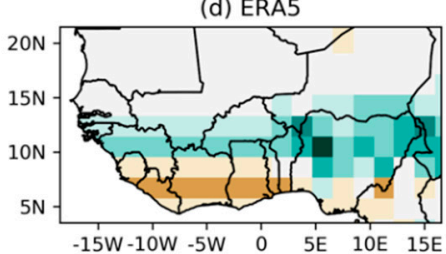

(b) GPCC

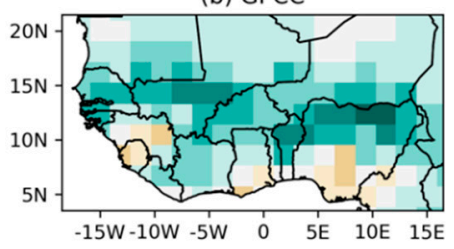

(e) ERA-interim

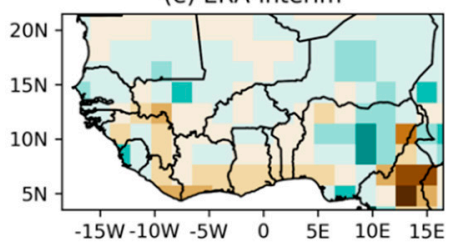

(g) MERRA2

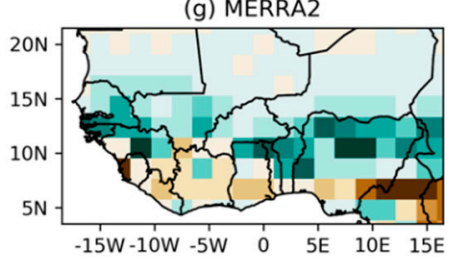

(c) CHIRPS

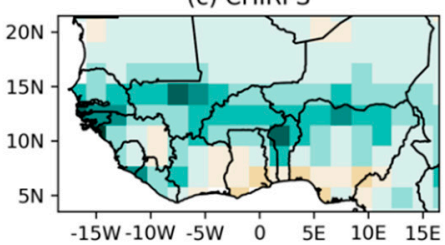

(f) JRA-55

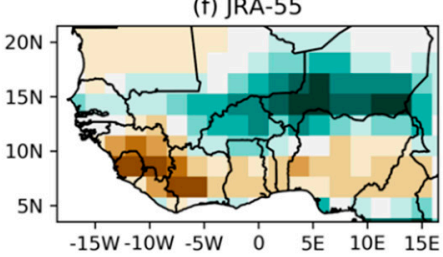

(h) NCEP-R2

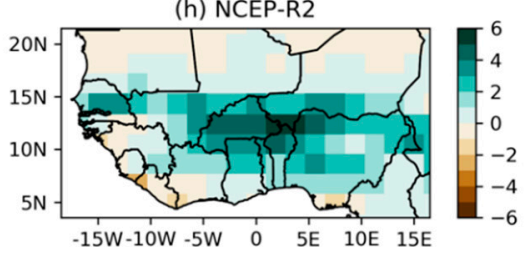

Figure 10. Spatial patterns of mean precipitation $\left(\mathrm{mm} \mathrm{day}^{-1}\right)$ for the month of August averaged for the difference in wet and dry consensus years within the period 1981-2016.

\section{Summary and Conclusions}

Climatology and variability of monthly rainfall observed in 1981-2016 are analysed using multiple observational datasets and five reanalysis datasets over West Africa, a region with an important lack of adequate in situ observations. The comparison of reanalysis products to gridded observational datasets demonstrates a coherence in capturing major features of the seasonal evolution of mean rainfall over the region, although the spread can be larger locally, in particular in mountainous regions and with respect to the northernmost position of the monsoon rainband. Not much difference is observed among observational datasets as they all display similar patterns in rainfall climatology and interannual variability. For domain average rainfall, the MERRA2 reanalysis dataset has the best performance in the summer monsoon rainfall estimates due to its relatively small bias from observational datasets. The largest rainfall variability in CRU is located over the western part of our domain, which also holds true for the other observational datasets and ERA-Interim, ERA5, and JRA55 reanalysis, since they all show relatively small differences in standard deviation over the region. In NCEP-R2, the maximum variation shifts to the central part of the region, while MERRA2 observes a long stretch of its peak variation over the central belt. On spatial characteristics, all reanalysis datasets, except ERA-Interim, capture the wetting trend in the Sahel, though generally over- or underestimating its magnitude. Other local trend patterns do not reflect the observational datasets and show large differences amongst reanalyses, in line with subregional studies in Ghana [21], and southern West Africa [62]. This highlights even larger uncertainties in reanalysis rainfall trends than were previously found amongst observational datasets over Africa [16], strongly discouraging the use of reanalysis rainfall fore trend studies. Considering the representation of interannual rainfall variability over West Africa, we further look at rainfall correlation with SSTs in the tropical Atlantic. ERA5, MERRA2, and NCEP-R2 closely reproduce the observed relationship of a negative correlation corresponding to a wetter Sahel when the tropical Atlantic is cooler, while the coast receives more rainfall with warm SSTs. ERA-Interim on the other hand, overestimates the negative correlation over the Sahel.

The JJAS precipitation patterns in all reanalysis datasets are consistent with the observed datasets. However, in large scale dry and wet years, defined here as El Niño-driven drought years and La Niña-driven wet years in the Sahel, differences in the corresponding displacement of the monsoon rainband become apparent in the reanalyses. Compared to observed characteristics, the rainband 
of MERRA2 stays a little south during consensus dry years, while JRA- 55 shifts too far north. The maximum of the rainband stays south of the Sahel during very strong El Niño years, therefore leaving the Sahel region drier. During consensus wet years (when La Niña events are strong), the rainband over West Africa shifts further north to about $15^{\circ} \mathrm{N}$, thereby leaving the Sahel region wetter. JRA-55 and NCEP-R2 capture the northward shift in the rainband during these years, with ERA5 and MERRA2 showing a weak northward shift in the rainband, although it stays above $10^{\circ} \mathrm{N}$, while ERA-Interim shows little coherence. Maximum precipitation is underestimated by ERA5 in the western parts and by NCEP-R2 on the eastern end of the region.

The tendency towards incorrect positioning of the rainband, in particular too far south, is a longstanding problem of WAM representation in NCEP and ECMWF reanalyses and has been identified in the past (e.g., $[63,64])$. Our results indicate the persistence of this bias in the newer reanalyses MERRA2 and ERA5.

In the evaluation of how well reanalysis datasets represent the West African precipitation, there is a difficulty in attributing discrepancies, since each reanalysis is limited by its own physical parameterizations and SST boundary conditions [65]. Since the hydrological cycle is a key driver of the resulting rainfall, large systematic differences in the representation of hydrological processes [66] can lead to discrepancies in reanalysis datasets. The study by [62] attributed rainfall biases over Central Africa predominantly to errors in moisture distribution, while they found circulations to be well represented in comparison to radiosonde data. Weak constraints for humidity in the data assimilation process are therefore likely to similarly hamper reanalysis skills for West African rainfall. Nevertheless, we find that some reanalyses do well in capturing the temporal interannual variability and seasonal spread in rainfall behaviour over West Africa (e.g., MERRA2, ERA5). Others like JRA-55 and NCEP-R2 better represent the northward meridional shift of the rainband, but performance remains spatially variable.

Overall, the considerable uncertainties in regional rainfall distribution in the reanalyses significantly reduce their usefulness for impact-oriented analyses and applications, for which observation-based datasets should be the first choice. However, reanalysis rainfall biases can be understood as the accumulated errors in the driving atmospheric fields, making it a valuable indicator for model performance and shortcomings.

Author Contributions: Conceptualization, K.A.Q. and F.N.; methodology, C.K., F.N., N.A.B.K. and K.A.Q.; formal analysis, F.N., K.T.Q. and K.A.Q.; data, K.A.Q., F.N. and K.T.Q.; writing—original draft preparation, K.A.Q., F.N., C.K., N.A.B.K., K.T.Q.; editing, N.A.B.K. and C.K. All authors have read and agreed to the published version of the manuscript.

Funding: This article was supported by AIMS Canada Resident Researcher in Climate Change Science fund at AIMS Rwanda, grant number 108246-001. F.N. and C.K. acknowledge funding from the UK's Natural Environment Research Council (NERC)/Department for International Development (DFID) Future Climate for Africa program, under AMMA-2050/CLOVER project (NE/M020428/1).

Acknowledgments: The authors would like to thank the European Center for Medium-Range Weather Forecast (ECMWF), the Japanese Meteorological Agency (JMA), the National Aeronautics and Space Administration (NASA), the National Centers for Environmental Prediction (NCEP-R2), Climatic Research Unit (CRU), Global Precipitation Climatology Center (GPCC), and the United States Geological Service (USGS) for making available datasets used in the study. The first author is grateful to the University of Cape Town for research assistance. All datasets used in the study are publicly available at the Royal Netherlands Meteorological Institute (KNMI) Climate Explorer website (https://climexp.knmi.nl/start.cgi); however, the CHIRPS dataset is available at https: //data.chc.ucsb.edu/products/CHIRPS-2.0/. The authors are grateful to the anonymous reviewers for their helpful comments.

Conflicts of Interest: The authors declare no conflict of interest. 


\section{References}

1. Hagos, S.M.; Cook, K.H. Dynamics of the West African monsoon jump. J. Clim. 2007, 20, 5264-5284. [CrossRef]

2. Niang, I.; Ruppel, O.C.; Abdrabo, M.A.; Essel, A.; Lennard, C.; Padgham, J.; Urquhart, P. Africa. In Climate Change 2014: Impacts, Adaptation, and Vulnerability. Part B: Regional Aspects. Contribution of Working Group II to the Fifth Assessment Report of the Intergovernmental Panel on Climate Change; Cambridge University Press: Cambridge, UK; New York, NY, USA, 2014; pp. 1199-1265.

3. Sylla, M.B.; Dell'Aquila, A.; Ruti, P.M.; Giorgi, F. Simulation of the intraseasonal and the interannual variability of rainfall over West Africa with RegCM3 during the monsoon period. Int. J. Climatol. 2010, 30, 1865-1883. [CrossRef]

4. Nicholson, S.E. The West African Sahel: A Review of Recent Studies on the Rainfall Regime and Its Interannual Variability. ISRN Meteorol. 2013, 2013, 1-32. [CrossRef]

5. Nicholson, S.E.; Ba, M.B.; Kim, J.Y. Rainfall in the Sahel during 1994. J. Clim. 1996, 9, 1673-1676. [CrossRef]

6. Nicholson, S.E. Dryland Climatology; Cambridge University Press: Cambridge, UK, 2011; ISBN 9780511973840.

7. Nkiaka, E.; Nawaz, N.R.; Lovett, J.C. Evaluating global reanalysis precipitation datasets with rain gauge measurements in the Sudano-Sahel region: Case study of the Logone catchment, Lake Chad Basin. Meteorol. Appl. 2017, 24, 9-18. [CrossRef]

8. Hewitson, B.C.; Reason, C.J.C.; Tennant, W.; Tadross, M.; Jack, C.; MacKellar, N.; Lennard, C.; Hansingo, K.; Walawege, R.; Mdoka, M. Dynamical Modelling of Present and Future Climate Systems; Techinical Report; South African Water Research Commission: Gezina, South Africa, 2004; ISBN 1-77005-280-1.

9. Donat, M.G.; Alexander, L.V.; Yang, H.; Durre, I.; Vose, R.; Dunn, R.J.H.; Willett, K.M.; Aguilar, E.; Brunet, M.; Caesar, J.; et al. Updated analyses of temperature and precipitation extreme indices since the beginning of the twentieth century: The HadEX2 dataset. J. Geophys. Res. Atmos. 2013, 118, 2098-2118. [CrossRef]

10. Bosilovich, M.G.; Chen, J.; Robertson, F.R.; Adler, R.F. Evaluation of global precipitation in reanalyses. J. Appl. Meteorol. Climatol. 2008, 47, 2279-2299. [CrossRef]

11. Le Coz, C.; Van De Giesen, N. Comparison of rainfall products over sub-saharan africa. J. Hydrometeorol. 2020, 21, 553-596. [CrossRef]

12. van der Linden, R.; Knippertz, P.; Fink, A.H.; Ingleby, B.; Maranan, M.; Benedetti, A. The influence of DACCIWA radiosonde data on the quality of ECMWF analyses and forecasts over southern West Africa. Q. J. R. Meteorol. Soc. 2020, 146, 1719-1739. [CrossRef]

13. Koutsouris, A.J.; Chen, D.; Lyon, S.W. Comparing global precipitation data sets in eastern Africa: A case study of Kilombero Valley, Tanzania. Int. J. Climatol. 2016, 36, 2000-2014. [CrossRef]

14. Acharya, S.C.; Nathan, R.; Wang, Q.J.; Su, C.-H.; Eizenberg, N. An evaluation of daily precipitation from a regional atmospheric reanalysis over Australia. Hydrol. Earth Syst. Sci. 2019, 23, 3387-3403. [CrossRef]

15. Jones, B.L.; Carabine, E.; Hickman, A.; Langston, L.; Moosa, S.; Mukanya, R. Exploring the role of climate science in supporting long-term adaptation and decision-making in sub-Saharan Africa; The Climate and Development Knowledge Network, Working Paper. 2014. Available online: https://www.preventionweb.net/ publications/view/37331 (accessed on 28 September 2020).

16. Maidment, R.I.; Allan, R.P.; Black, E. Recent observed and simulated changes in precipitation over Africa. Geophys. Res. Lett. 2015, 42, 8155-8164. [CrossRef]

17. Manney, G.L.; Hegglin, M.I.; Lawrence, Z.D.; Wargan, K.; Millán, L.F.; Schwartz, M.J.; Santee, M.L.; Lambert, A.; Pawson, S.; Knosp, B.W.; et al. Reanalysis comparisons of upper tropospheric-lower stratospheric jets and multiple tropopauses. Atmos. Chem. Phys. 2017, 17, 11541-11566. [CrossRef]

18. Thorne, P.W.; Vose, R.S. Reanalyses suitable for characterizing long-term trends. Bull. Am. Meteorol. Soc. 2010, 91, 353-361. [CrossRef]

19. Walters, C.K.; Winkler, J.A.; Husseini, S.; Keeling, R.; Nikolic, J.; Zhong, S. Low-level jets in the North American Regional Reanalysis (NARR): A comparison with rawinsonde observations. J. Appl. Meteorol. Climatol. 2014, 53, 2093-2113. [CrossRef]

20. Zhang, Q.; Körnich, H.; Holmgren, K. How well do reanalyses represent the southern African precipitation? Clim. Dyn. 2013, 40, 951-962. [CrossRef] 
21. Manzanas, R.; Amekudzi, L.K.; Preko, K.; Herrera, S.; Gutiérrez, J.M. Precipitation variability and trends in Ghana: An intercomparison of observational and reanalysis products. Clim. Change 2014, 124, 805-819. [CrossRef]

22. Egbebiyi, T.S.; Lennard, C.; Crespo, O.; Mukwenha, P.; Lawal, S.; Quagraine, K. Assessing future spatio-temporal changes in crop suitability and planting season over West Africa: Using the concept of crop-climate departure. Climate 2019, 7, 102. [CrossRef]

23. Sultan, B.; Gaetani, M. Agriculture in West Africa in the twenty-first century: Climate change and impacts scenarios, and potential for adaptation. Front. Plant Sci. 2016, 7, 1-20. [CrossRef]

24. Sylla, M.B.; Diallo, I.; Pal, S.J. West African Monsoon in State-of-the-Science Regional Climate Models. In Climate Variability—Regional and Thematic Patterns; InTech: London, UK, 2013; pp. 3-36.

25. Klutse, N.A.B.; Ajayi, V.O.; Gbobaniyi, E.O.; Egbebiyi, T.S.; Kouadio, K.; Nkrumah, F.; Quagraine, K.A.; Olusegun, C.; Diasso, U.J.; Abiodun, B.J.; et al. Potential impact of $1.5{ }^{\circ} \mathrm{C}$ and $2{ }^{\circ} \mathrm{C}$ global warming on consecutive dry and wet days over West Africa. Environ. Res. Lett. 2018, 13, 1-6. [CrossRef]

26. Harris, I.; Jones, P.D.; Osborn, T.J.; Lister, D.H. Updated high-resolution grids of monthly climatic observations-The CRU TS3.10 Dataset. Int. J. Climatol. 2014, 34, 623-642.

27. Becker, A.; Finger, P.; Meyer-Christoffer, A.; Rudolf, B.; Schamm, K.; Schneider, U.; Ziese, M. A description of the global land-surface precipitation data products of the Global Precipitation Climatology Centre with sample applications including centennial (trend) analysis from 1901-present. Earth Syst. Sci. Data 2013, 5, 71-99. [CrossRef]

28. Schneider, U.; Becker, A.; Finger, P.; Meyer-Christoffer, A.; Ziese, M.; Rudolf, B. GPCC's new land surface precipitation climatology based on quality-controlled in situ data and its role in quantifying the global water cycle. Theor. Appl. Climatol. 2014, 115, 15-40. [CrossRef]

29. Diaconescu, E.P.; Gachon, P.; Scinocca, J.; Laprise, R. Evaluation of daily precipitation statistics and monsoon onset/retreat over western Sahel in multiple data sets. Clim. Dyn. 2015, 45, 1325-1354. [CrossRef]

30. Lorenz, C.; Kunstmann, H. The hydrological cycle in three state-of-the-art reanalyses: Intercomparison and performance analysis. J. Hydrometeorol. 2012, 13, 1397-1420. [CrossRef]

31. Maidment, R.I.; Grimes, D.; Allan, R.P.; Tarnavsky, E.; Stringer, M.; Hewison, T.; Roebeling, R.; Black, E. Atmospheres And Time series (TARCAT) data set. J. Geophys. Res. Atmos. 2014, 119, 10619-10644.

32. Funk, C.; Peterson, P.; Landsfeld, M.; Pedreros, D.; Verdin, J.; Shukla, S.; Husak, G.; Rowland, J.; Harrison, L.; Hoell, A.; et al. The climate hazards infrared precipitation with stations-A new environmental record for monitoring extremes. Sci. Data 2015, 2, 150066. [CrossRef]

33. Hersbach, H.; Bell, B.; Berrisford, P.; Hirahara, S.; Horányi, A.; Muñoz-Sabater, J.; Nicolas, J.; Peubey, C.; Radu, R.; Schepers, D.; et al. The ERA5 global reanalysis. Q. J. R. Meteorol. Soc. 2020, 1-51.

34. Dee, D.P.; Uppala, S.M.; Simmons, A.J.; Berrisford, P.; Poli, P.; Kobayashi, S.; Andrae, U.; Balmaseda, M.A.; Balsamo, G.; Bauer, P.; et al. The ERA-Interim reanalysis: configuration and performance of the data assimilation system. Q. J. R. Meteorol. Soc. 2011, 137, 553-597. [CrossRef]

35. Kobayashi, S.; Ota, Y.; Harada, Y.; Ebita, A.; Moriya, M.; Onoda, H.; Onogi, K.; Kamahori, H.; Kobayashi, C.; Endo, H.; et al. The JRA-55 reanalysis: General specifications and basic characteristics. J. Meteorol. Soc. Japan 2015, 93, 5-48. [CrossRef]

36. Huang, Y.; Dong, X.; Qiu, S.; Xi, B.; Dolinar, E.K.; Stanfield, R.E. Quantifying the uncertainties of reanalyzed Arctic cloud and radiation properties using satellite surface observations. J. Clim. 2017, 30, 8007-8029. [CrossRef]

37. Bosilovich, M.G.; Robertson, F.R.; Takacs, L.; Molod, A.; Mocko, D. Atmospheric water balance and variability in the MERRA-2 reanalysis. J. Clim. 2017, 30, 1177-1196. [CrossRef]

38. Gelaro, R.; McCarty, W.; Suárez, M.J.; Todling, R.; Molod, A.; Takacs, L.; Randles, C.A.; Darmenov, A.; Bosilovich, M.G.; Reichle, R.; et al. The modern-era retrospective analysis for research and applications, version 2 (MERRA-2). J. Clim. 2017, 30, 5419-5454. [CrossRef] [PubMed]

39. Kanamitsu, M.; Ebisuzaki, W.; Woollen, J.; Yang, S.-K.; Hnilo, J.J.; Fiorino, M.; Potter, G.L. NCEP-DOE AMIP-II Renalalysys (R-2). Bull. Am. Meteorol. Soc. 2002, 83, 1631-1643. [CrossRef]

40. Mann, H.B. Nonparametric Tests Against Trend. Econometrica 1945, 13, 245. [CrossRef]

41. Kendall, M.G. Rank Correlation Methods, 5th ed.; Griffin, C., Ed.; Oxford University Press: London, UK, 1975; ISBN 978-0195208375. 
42. Van der Walt, S.; Aivazis, M. The NumPy Array: A Structure for Efficient Numerical Computation, Computing in Science \& Engineering. Comput. Sci. Eng. 2011, 13, 22-30.

43. McKinney, W. Data Structures for Statistical Computing in Python. In Proceedings of the 9th Python in Science Conference, Austin, TX, USA, 28 June-3 July 2010; pp. 51-56.

44. Hoyer, S.; Hamman, J.J. xarray: N-D labeled Arrays and Datasets in Python. J. Open Res. Softw. 2017, 5, 1-6. [CrossRef]

45. Hunter, J.D. Matplotlib: A 2D graphics environment. Comput. Sci. Eng. 2007, 9, 90-95. [CrossRef]

46. Maussion, F.; Siller, M.; Rothenberg, D.; Roth, T.; Dusch, M.; Landmann, J. Salem Python Package. Available online: https://zenodo.org/record/1295582 (accessed on 28 September 2020).

47. Salack, S.; Klein, C.; Giannini, A.; Sarr, B.; Worou, O.N.; Belko, N.; Bliefernicht, J.; Kunstman, H. Global warming induced hybrid rainy seasons in the Sahel. Environ. Res. Lett. 2016, 11, 104008. [CrossRef]

48. Fontaine, B.; Bigot, S. West African rainfall deficits and sea surface temperatures. Int. J. Climatol. 1993, 13, 271-285.

49. Fontaine, B.; Janicot, S. Sea Surface Temperature Fields Associated with West African Rainfall Anomaly Types. J. Clim. 1996, 9, 2935-2940. [CrossRef]

50. Polo, I.; Lazar, A.; Rodriguez-Fonseca, B.; Arnault, S. Oceanic Kelvin waves and tropical Atlantic intraseasonal variability: 1. Kelvin wave characterization. J. Geophys. Res. Ocean. 2008, 113, 1-18. [CrossRef]

51. Nkrumah, F. Dynamic Analysis of the West African Monsoon and Its Variability over Ghana. Master's Thesis, University of Cape Coast, Cape Coast, Ghana, 2014.

52. Cook, K.H.; Vizy, E.K. Detection and analysis of an amplified warming of the Sahara Desert. J. Clim. 2015, 28, 6560-6580. [CrossRef]

53. Gaetani, M.; Flamant, C.; Bastin, S.; Janicot, S.; Lavaysse, C.; Hourdin, F.; Braconnot, P.; Bony, S. West African monsoon dynamics and precipitation: the competition between global SST warming and CO2 increase in CMIP5 idealized simulations. Clim. Dyn. 2017, 48, 1353-1373. [CrossRef]

54. Giannini, A.; Saravanan, R.; Chang, P. Long-term simulation of global dust distribution with the GOCART model: Correlation with North Atlantic Oscillation. Science 2004, 302, 1027-1030. [CrossRef]

55. Janicot, S. Spatiotemporal Variability of West African Rainfall. Part II: Associated Surface and Airmass Characteristics. J. Clim. 1992, 5, 499-511. [CrossRef]

56. Lutz, K.; Jacobeit, J.; Rathmann, J. Atlantic warm and cold water events and impact on African west coast precipitation. Int. J. Climatol. 2015, 35, 128-141. [CrossRef]

57. Losada, T.; Rodríguez-Fonseca, B.; Janicot, S.; Gervois, S.; Chauvin, F.; Ruti, P. A multi-model approach to the Atlantic Equatorial mode: Impact on the West African monsoon. Clim. Dyn. 2010, 35, 29-43. [CrossRef]

58. Zebiak, S.E. Air-Sea Interaction in the Equitorial Atlantic Region. J. Clim. 1993, 6, 1567-1586. [CrossRef]

59. Balas, N.; Nicholson, S.E.; Klotter, D. The relationship of rainfall variability in West Central Africa to sea-surface temperature fluctuation. Int. J. Climatol. 2008, 27, 1335-1349. [CrossRef]

60. Enfield, D.B.; Mestas-Nuñez, A.M.; Mayer, D.A.; Cid-Serrano, L. How ubiquitous is the dipole relationship in tropical Atlantic sea surface temperatures? J. Geophys. Res. Ocean. 1999, 104, 7841-7848. [CrossRef]

61. Reynolds, R.W.; Rayner, N.A.; Smith, T.M.; Stokes, D.C.; Wang, W. An improved in situ and satellite SST analysis for climate. J. Clim. 2002, 15, 1609-1625. [CrossRef]

62. Hua, W.; Zhou, L.; Nicholson, S.E.; Chen, H.; Qin, M. Assessing reanalysis data for understanding rainfall climatology and variability over Central Equatorial Africa. Clim. Dyn. 2019, 53, 651-669. [CrossRef]

63. Xue, Y.; e Sales, F.; Lau, W.K.M.; Boone, A.; Feng, J.; Dirmeyer, P.; Guo, Z.; Kim, K.M.; Kitoh, A.; Kumar, V.; et al. Intercomparison and analyses of the climatology of the West African Monsoon in the West African Monsoon Modeling and Evaluation project (WAMME) first model intercomparison experiment. Clim. Dyn. 2010, 35, 3-27. [CrossRef]

64. Druyan, L.M.; Fulakeza, M. Downscaling reanalysis over continental Africa with a regional model: NCEP versus ERA Interim forcing. Clim. Res. 2013, 56, 181-196. [CrossRef] 
65. Lin, R.; Zhou, T.; Qian, Y. Evaluation of Global Monsoon Precipitation Changes based on Five Reanalysis Datasets. J. Clim. 2014, 27, 1271-1289. [CrossRef]

66. Trenberth, K.E.; Fasullo, J.T.; Mackaro, J. Atmospheric moisture transports from ocean to land and global energy flows in reanalyses. J. Clim. 2011, 24, 4907-4924. [CrossRef]

(C) 2020 by the authors. Licensee MDPI, Basel, Switzerland. This article is an open access article distributed under the terms and conditions of the Creative Commons Attribution (CC BY) license (http://creativecommons.org/licenses/by/4.0/). 